\title{
An Investigation of the Concept and Extensions of Wealth according to the Intellectuals of Qajar Nasir al-Din Shah Era
}

\begin{abstract}
Elnaz Abeshloo*
Alzahra university, Iran

*Corresponding Author: Elnaz Abeshloo, Alzahra University, Iran

Abstract: Iranian society was a poor and powerless society under Nasir al-Din Shah. The people of this era had their particular vision of wealth. Their definition of wealth was a variation of the traditional definition based on the traditional and underdeveloped conditions of Qajar era. But in the west there was another view of wealth and wealth accumulation and massive volume of wealth and the development that existed in western societies in nineteenth century caused a number of Iranian intellectuals offer a new and more updated definition of this category. Such figures as Kermani, Talbov, Maraghei, Mirza Malkom Khan and the like, struggled to define real wealth and encourage the Shah and people to spend on education and expansion of industries and mines instead of purposeless accumulation of gold and jewelries and adding to the number of profitless lands and farms. Their definitions of the concept of wealth and their solutions for unprecedented increase of wealth in the sense that is prevalent in the west will be assayed in the current essay.
\end{abstract}

Keywords: Intellectual, Nasir al-Din Shah Era, Wealth

\section{INTRODUCTION}

The debate of various concepts including wealth and their background contains a special attraction that brings about a particular motive in the researcher. The aim of current study is realizing the concept of wealth from the viewpoints of a number of intellectuals in the era of Nasir al-Din Shah, i.e. Zein al-Abedin Maraghei, Mirza Aqa Khan Kermani, Abd al-Rahim Talbov and Mokhbir al-Saltanah. Qajar era and particularly Nasir al-Din Shah Era is one of the important points of Iranian history. Emergence of modern ideas in this era left important effects on significant political, social, economic and cultural domains and challanged many categories, concepts, values and norms of society and in this process propounded numerous new concepts and extensions. In this course, one of the most important social classes that engaged itself with these categories and concepts was the intellectuals and elites in the society. This social class was also known as modernists and anti-reactionaries, and had such features as truth-seeking, rationalism, critical vision and sense of responsibility regarding the status quo and effort for social reform and promotion of it to desirable status, and contemplated on many of these notions. The impact of modern western ideas on the intellectuals changed their views, beliefs, norms and notions and in this way criticized the traditional vision of the society.

\section{ZEIN AL-ABEDIN MARAGHEI AND NATION SPIRIT}

Zein al-Abedin Maraghei is one of the intellectuals of Nasir al-Din Shah era who offers interesting debates of money and wealth. The most important debate that can be found in his book entitled Siahatnameh is his comment of the currency that were transferred from the country to abroad in this era as articulated in the following words, "from our country massive amounts of money - that is the nation spirit - enters their (westerners) country's stomach". The national treasury was conceived by him as the country's stomach. ${ }^{2}$ According to Maraghei, whenever the national treasury - that is the country's stomach - is empty, "people and farmers pour what they have earned through personal efforts of cash and goods into the treasury in order to fill this empty stomach and help the government to continue to work. Then, government is required to take care of the people more and more" 3 . In fact, he has considered the national treasury so important, he would say, that to conserve it the

\footnotetext{
${ }^{1}$ Maragheii, Zeinolabedin siahatnameh Maragheii, Tehran: Agah, 2006, Vol 1, p. 195

${ }^{2}$ Ibid, p 196

${ }^{3}$ Ibid, p 116
} 
government needs to take utmost care of the people in order not see the treasury empty any time and in his own terms, not to lose its food. On the other hand, Iranian currency loses its value in this era and the intellectuals continuously asked for revision of monetary policies. ${ }^{4}$

Of course, this was an issue that Qajar regime never paid any attention to it and made countless oppressions to the people. According to Willem Floor, "lower classes without any exaggeration are like sheep that are kept just for their wool and usually they are so deep sheared in a delicate fashion that nothing remains for them at all and they lose all their value. The greed is so high that the hen that lays golden eggs is often killed" 5

\section{Maraghei AND Hidden Wealth}

According to Maraghei, one of the goods the owner of which was declared a wealthy man specifically in Tabriz which is addressed by Maraghei - has been decorative expensive goods. Maraghei states that in this era "people used to spend their money on buying luxurious chandeliers which were usually seen as objects of pride and honor" ${ }^{\prime \prime}$. In fact, having such luxurious items had been considered to be a sign of wealthiness and people sought to show their affluence with such things. Maraghei speaks through Ibrahim Beig the hero of his own story and criticizes the squander of Tabriz people and states "these are transient ornaments and wealth is other thing"7.

In fact, luxuries are considered by all nations to be signs of affluence but in Qajar era as such they were declared to be the wealth itself. Since in many epochs of Qajar history there were not so many ways for making more money and having more money would have even endangered one's life and property people preferred to spend their money for buying luxurious items and jewelries instead of investing on commerce or industries. Then, the dangers that threatened people's life and property had been one of the factors that caused the accumulation of capitals and their stillness. "In a country where money - let alone financial and productive properties - is always threatened to be confiscated and even a Khan can seizure people's properties under minor pretexts the accumulation of capital and commercial activities in the size that did happen in Iran was truly unbelievable"8.

The need for luxuries and magnificence was visible even among the poor people of the society and in the villages where residents were deprived from basic requirements there were always a number of goldsmith, silversmith and embroidering artists who had good income. ${ }^{9}$

Numerous luxurious symbols were prevalent among people in Qajar era most of which can be found in itineraries. For example, in Qajar era, longer hooka represented one higher social status and affluence. The rich and of course Qajar Shahs used hooka as a banner to show their magnificence and sought to decorate their hooka as much as they could. Fatali Shah Qajar liked his servant to keep royal ornamented hooka by the throne so that whenever Shah preferred to be able to use it. ${ }^{10}$ Another sign of wealth and power in Iran was robe of honor. Iranians were increasingly interested in getting robe of honor from the Shah and they valued it much. ${ }^{11}$

Someone who was honored by Shah and received a robe of honor would have used it for ostentation and always wore it. According to the reports of Heinrich Karl Brugsch, "one of the items that did distinguish people from each other was their hats and from one's hat you could identify him. The servants and bondmen used a special brown high hat made of felt, middle classes and rich people used black high hats made of animal skins with a tilted tip and every one used a specific skin hat in various forms depending on his financial power. The most precious one of these hats is made of skins brought from Bokhara that are the skins of black sheep that live in Bokhara" ${ }^{12}$.Yoshida Masaharu also

\footnotetext{
${ }_{5}^{4}$ Alizade Birjandi, Zahra gasseri's Government and New Discourses, Tehran: Hirmand, 2011, p. 120

5 Flora, Willem, Essays on Iranian Social History in the Qajar era, Tehran: Toos, Vol. 2, p. 21

${ }^{6}$ Siahatnameie Ebrahimbeig, Vol, 1, p.199

${ }^{7}$ Ibid, 198

${ }^{8}$ Katouzian, Mohammad Ali, Political Economy of Iran from constitutional Revolution to the End of Pahlavi Dynasty, Tehran, Center, 2014, p. 62)

${ }^{9}$ D`Allemagne, Henry, From Khorasan to Bakhtiari, Translated by Gholamreza Samiee, 1999, p. 156 (d`Allmanage, 1999)

${ }_{10}$ Mostofi, Abdollah, A Description of My Life, Tehran: Zavaar, 2009. Volume 1, p. 404

11 Serena, Carl, People and Spectacles of Iran, Tehran: Noor, 1984, p. 113

${ }^{12}$ Brugesch, Henrich, A Journey to the Court of the Sultan Sahebgaran, Tehran: Center, 1995, p. 127
} 
describes the cloths of people in Tehran of Nasir al-Din Shah era as follows: "Tehran elders and high ranked dignitaries from Shah to ministers and rich people used black hats made of the skin of black lamb of Hashtarkhan. They wore a shirt with open collar and sleeves with pants and leather shoes"13. According to the reports of Dr. Polack, an enormous amount of money was transferred to abroad for buying skins from Bokhara because rich and wealthy people liked these special hats. ${ }^{14}$

Besides these all, Iranian affluent people liked to have numerous servants and bondmen in whom they used to take pride. According to Polack, these servants were so numerous whose number could not be imagined so easily. ${ }^{15}$

Zein al-Abedin Maraghei in his Siahatnameh begins his discussion of the necessity of the formation of companies with a pungent criticism of the way that Iranian business people trade and invest. In his view, "class of business men is not at all concerned about the growth of trade and its development and they pursue their work in the way that their ancestors did. In Tehran there is no company that would promote national products" 16

His criticism of the businesspersons is first that they are following their fathers in trade and just imitate them; while the ways of acquiring wealth have changed in the world as compared to the past. $\mathrm{He}$ also mentions another reason for this and it is the lack of sense of security among people; because the first prerequisite for the foundation of a company is that the partners can trust each other; but "even despite sufficient capital that is at the disposal of a number of people they have not confidence in each other. Even in transactions they approach each other with utmost caution and each one of them thinks of the ways to undermine the other." ${ }^{\text {17 }}$ The other reason for the unwillingness of the businessmen for foundation of companies is the lack of sense of patriotism. "The businesses and traders are quarreling for money ... no one has any concern of the country and cares not of it neither inside nor outside. Everyone is partial in action and belief. They are dead but alive and vice versa". ${ }^{18}$ In his work, Maraghei criticizes the people of various cities like Mashhad and writes that although such cities as Mashhad has numerous capabilities and a massive wealth is hidden in it, but there is no single company there. This is while the people are wealthy and there are also countless commercial goods like carpet and opium. ${ }^{19}$ Or for example in Azerbaijan that has also great potentiality for every type of commerce and production of wealth, there has been no profit-making company. ${ }^{20}$ The problem, as Burgees suggests, is that the most profitable business in such city as Tabriz was usury, i.e. lending money in return of such bonds as jewelries with the interest rates of 20,30 and even in some cases 120 percent. $^{21}$

Shah's interest in money and bribery has been another economic disaster in Iran in this era. "Even Amin al-Sultan - Chancellor of Nasir al-Din Shah - had confessed that Shah's excessive interest in money has reached the point that he prioritizes his greed for money over the personal and national interests",22

Lord Curzon writes: "From my narrative it will be seen that, in spite of her retrograde condition, which a study of history does more than anything else to accentuate, Persia, so far from being deficient, is richly endowed with those natural resource which it is a nation's own fault if it does not transmute into gold. Physical conditions, such as the scarcity of navigable rivers, the long distances to be traversed, and the interference of great mountain barriers between the interior and the sea, undoubtedly retard the development of many of these resources. But the apathy of the people and the neglect of the Government are greater obstacles. ${ }^{, 23}$

\footnotetext{
13 Masaharu, Yoshida, Yoshida Masaharu's Mission to Persia, Mashhad: Astane Qodse Razavi, 1994. p. 108

14 Polak, Jakob Eduard, Persia, the land and its inhabitants; Ethnographic descriptions, Translated by Keikavous Jahandari, Tehran: Kharazmi, 1982, p. 104

${ }^{15}$ Ibid, p 166

${ }^{16}$ Siahatnamehie Ebrahim beig, 2006. Vol, 1, p.195

${ }^{17}$ Ibid, p 139

${ }^{18}$ Ibid, p 140

${ }^{19}$ Ibid, p 157

${ }^{20}$ Ibid, p 153

${ }^{21}$ Burgess, Charles and Edward, Letters from Persia Written, New York: Public Library, 1942, p.105

22 Izadi, Syrous and Mitradat Izadi, research on modern history of Iran, Tehran: Varjevand, 2003, p. 254

${ }^{23}$ Curzon, George N, Persia and the Persian question, Vol. 2, Frank Cass \& Co. LTD, 1966, p 527
} 
Of course, in some cases we should understand the conditions of businessmen due to the country's chaotic situation. For example, though according to official governmental laws, the traders and business people were not forced to pay any tax, "Shah and the government always extorted the traders through force". "Persian governors are always on the look-out for money, and if a rich man had a fine exterior to his house it would not be long before much of his wealth would find its way into the governor's pocket." 25

However, in some points of Qajar era we are witness to the relative growth of commerce. For example, "both Abbas Mirza the Crown Prince and Amir Kabir were interested in the establishment of textile, sugar and military factories" 26

Nasir al-Din Shah in his travel to Europe got informed of the affluent wealth of those countries and became interested in discovery of gold and diam0ond. ${ }^{27}$

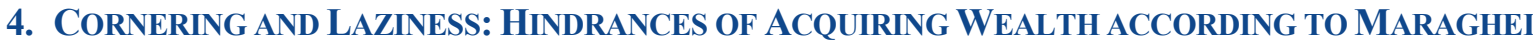

Maraghei has paid a considerable attention to the modern ways of wealth accumulation like establishment of companies and unions and joint ventures and criticized the past cruel ways like cornering. As to this he writes: "it is truly a disgrace that there is no sign of national products in the markets. The wheat is cornered in the barns and even they prefer to pour the wheat into Aras River instead of giving it to the poor and ask heavy prices for a little amount of wheat. The poor people are ready to pay for the wheat but the cruel people continue to corner this basic need of the society" ${ }^{28}$ In such conditions there remains no motive in people to acquire wealth; because with exacerbation of life conditions and expansion of oppression and injustice that emerge following the pressures resulted from the cornering otherworldly ideas increased. Insofar as "whenever a number of people gather together somewhere they would say that the world is these five days. One should think for his otherworld" ${ }^{29}$ Some of the proverbs that were used in Qajar era and had a pessimistic view of wealth accumulation and in other words, they promoted deterministic thoughts, consisted of:

"The wider roof the more snow to plough". 30

"When we are dead no matter whether the world is sea or a quagmire" 31

"A grain of gold is more valuable than tons of force",32

"Gold does not speak",33

All these proverbs revel the deep roots of such deterministic thoughts in the mind of people. In fact, these proverbs were used to justify the lack of wealth and they are still used for this cause. Our society has become used to these ideas. On the other hand, there are a plenty of proverbs that suggest one not to get himself involved in big deals. For example,

"Stretch your legs as far as your mat allows".

"World passes in the way you deem it".

"Huge stone is a sign of lack of will for strike".

"When you cannot carry a stone it would be better to kiss it and leave it stand wherever it is".

"Last resort is burning and putting up with it",34

"The poor is an undefeated fort",

${ }^{24}$ Vahram, Gholamreza, Political System and Social Organizations of Iran in the Qajar era, Tehran: Moeein, 2006, p. 202

${ }^{25}$ Rice, C, Colliver, Persian women and their ways, London: Seeley, 1923. P. 168

${ }^{26}$ Political system and social organizations of Iran during Qajar era, 2006. p. 204)

${ }^{27}$ Milani, Abbas, Modernity and Modernization in Iran, Tehran: Akhtaran, 1382, p. 137

${ }^{28}$ Ibid, p 199

${ }^{29}$ Ibid, p 214

${ }^{30}$ Brugesch, Heinrich, Journey of The K. Prussian Legation to Persia, Translated by Majid Jalilvand, Tehran: Center, 1995. p.117

${ }^{31}$ A Journey to the Court of the Sultan Sahebgaran, p. 132

${ }^{32}$ Ibid, p 132

${ }^{33}$ Ibid, 130

${ }^{34}$ vol 1. P. 130 
In fact, unemployment, laziness and involving oneself with the marginal affairs instead of engaging with basic things like work and education are among the things that can be seen in all writings across the Qajar Era. It was indeed for this reason that Iranians did prefer to seek after situations where they can have easy access to money no matter from which way instead of hard working. Haji Pirzade saw this with his eyes and recorded it in his memories when he travelled to Shiraz. He writes: people of Fars are lazy and although Fars has fertile lands with affluent water resources the people are not interested in farming and if the landlord does not care of his own land the servants would destroy it and turn to a desert. ${ }^{36}$ Admittedly, in such an environment where the laziness and hatred of rich people prevail and even with affluent natural resources no one takes any concrete step, we cannot expect anyone to be enthusiastic for life and business. To put it otherwise, "wealth in Iran was not considered in the past as an advantage". ${ }^{37}$ Therefore, in fact, as Mr. Ali Reza Qoli notes in his work, wealth in many epochs in Iran, among which Qajar era is not an exception, was not considered significant and instead the poverty was highlighted. In other words, "the poor is an udefeated fort" " "means that the man who does not have anything is like an armored castle that cannot be encroached in anyway. The fact is that since he does not have any money no one can do anything to him" ${ }^{39}$. As to the reason of stagnation of agriculture in Maraghe, Maraghei states: "in my view, the main cause of all these destructions is unemployment and lack of knowledge and consciousness". ${ }^{40}$

"As we said earlier, the people in the city are satisfied with their daily livelihood. They are not willing to take any further step. Self-indulgence has permeated to their whole existence" ${ }^{41}$

Land owning and excessive attention to land for acquiring wealth are among the issues that have been criticized by Maraghei. When the relations of Qajar regime grow with other countries and many intellectuals travelled to abroad the ideas of land owning gradually started to change; because they saw that there are more profitable ways than land owning through which one can earn wealth and create jobs. Maraghei criticizes the clerics for their greed for owning lands and writes: "their primary intention is to own a number of fertile villages in any possible way" ${ }^{42} \mathrm{He}$ even levels the same objections against the traders who were also interested more in buying lands and villages. ${ }^{43}$ In fact, although numerous years have passed since Qajar era and many changes have occurred in the country, we are still witness to the same problems at least in the contemporary Tehran and citizens prefer to act like their ancestors in Qajar era in buying and selling land and houses. ${ }^{44}$

\section{AQA KHAN KERMANI ON WEALTH}

According to Kermani, "in every country the first means of happiness and prosperity is affluence. Affluence is the basis of all nobilities and fortunes of human communities and individuals and all these can be achieved only through wealth ... What is affluence? Is money the affluence? No, money is never the affluence. No wise person would ever consider money to be affluence. Affluence that is also called wealth and prosperity is not merely the pains and efforts of human beings ... Money cannot feed the hungry, it cannot quench one's thirst. It neither protects man against heat nor it is able to deny the cold. If we disregard its application as a means of transaction money would have no difference from the stones that can be found in the allies and deserts. Affluence is not tantamount to money" 45

On the other hand, he considers the country to be the wealth ${ }^{46}$ and argues that acquisition of consciousness and modern sciences is possible via the wealth that exists in the country. In this regard

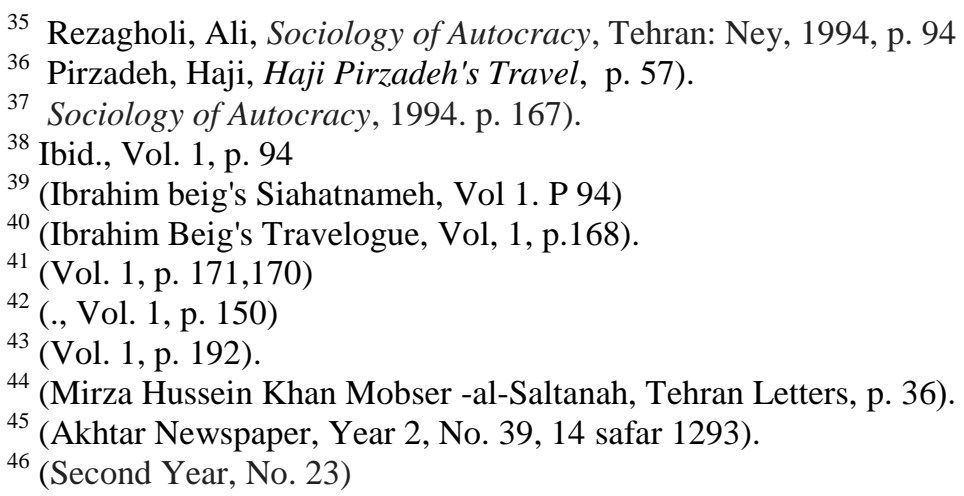


he writes in Akhtar Newspaper: "It is national wealth and resources that allows us to facilitate the generalization of sciences and knowledge and consciousness development. If national wealth cannot address this need how can we ever develop sciences and raise consciousness? This wealth can be earned through knowledge. It is reached through consciousness. An ignorant man can never own any personal wealth" ${ }^{, 7}$

Here Kermani establishes a direct relationship between knowledge and wealth; because earning knowledge depends on the existence of wealth in the country and wealth can be preserved through knowledge. Another index of affluence and wealth according to Kermani is constructing the infertile lands. He writes: "all these arid and barren lands that have been abandoned around the country can be constructed and make us affluent. We should work on these lands and after growing crops the harvest should be spend for good intentions" 48 . Accordingly, land alone cannot be considered wealth. The reality is that "the land owners including the Ilkhans and the head of tribes in the whole Qajar era were the most powerful elements in the country"49

Among the other pillars of affluence and wealth that are discussed by Kermani is railways. According to Kermani, railways construction in Iran is more necessary than anything else. Of course, "other roads should also be paved in order to facilitate the transportation of goods and passengers" ${ }^{\text {"50 }}$. In this regard, Kermani raises numerous criticism against the government that did not pay then any attention to road pavement. Miza Aqa Khan considers the people as another index of affluence. "Habitability of a land and country is evaluated according to the number of people who live in that country. The more is the number of people of a country the more affluent is the country"

According to the author, the most important and interesting note that has remained from Mirza Aqa Khan of wealth is this quotation. Kermani suggests that one of the conditions of prosperity of a country is affluence and wealth. He believes that population, that was highlighted by the intellectual and writers of Qajar era as power factors, should be considered as the second factor after wealth. The relationship that Kermani establishes between the increase of wealth and population increase is reciprocal like the relationship between knowledge and wealth in the sense that they are interrelated and each one's existence depends on the existence of the other. ${ }^{52}$ The cycle of security, affluence, wealth and increasing population is one the cases that has been discussed by Kermani in Akhtar Newspaper. Another prerequisite of wealth increase in a country is the balance of goods transaction.

The other factor that can be effective in the increase of wealth and affluence is the expansion of industries. As this point he writes: "taking advantage of wealth and natural resources of the countries that are governed by the Ottomans does indeed depend on the expansion of industries and farming and trade affairs ${ }^{, 53}$. Examples and comparisons that are referred to by Mirza Aqa Khan in order to demonstrate his own arguments are interesting as such. As to the importance of development of industries and its impact on the wealth increase he speaks of the discovery of America by Spain and states: "in the history of western lands we have seen that America was discovered by the Spain and tons of resources and money were shipped into Spain but since there was no industry and technology it is now France and England that are transferring the money of all world to Paris and London"s4. With this example the role and significance of knowledge and industry in affluence and wealth is specified well.

Mirza Aqa Khan Kermani provides an answer and solution for those who use religion as a pretext to oppose the development of sciences and industries. His solution was that we can accommodate companies with the religious laws and "for farming we can found investment funds" 55 As a result, summarizing the cases that have been noted by Kermani one can say that he has considered the true

\footnotetext{
${ }^{47}$ (the second year, No. 25, Saturdays 23 Muharram 1293).

48 (the second year, No. 40, Saturdays 15 safar 1293)

49 (. Mohammad Ali Katouzian, Government and Society in Iran, p. 6).

50 (the second year, No. 40, Saturdays 15 safar 1293)

51 (Second year, No. 47, Rabi ul Awal, 1293).

52 (Second year, No. 59, 18 Rabi ul Awal, 1293)

${ }^{53}$ Second year, No. 20, 29 Rabi ul Awal, 1294)

54 (Second year, No. 47, 1Rabi ul Awal, 1293)

55 (Second year, No. 40, 15 safar, 1294).
} 
wealth to be contingent upon the development of sciences, technologies, industries, security and rights, freedom and the like. Thus, one can state that the studies that have been conducted by him about the meaning of wealth and its real, correct and modern methods were all comparatively higher than his contemporary intellectuals were.

\section{Knowledge the Most Significant Path to Wealth in the Eyes of Mirza Aqa Khan KERMANI}

In the number 11 of Akhtar Newspaper, he raises a question and he answers it himself. He asks the following question: what is the basis of the wealth and order of a country? Then he answers that this basis is one thing and it is knowledge and wisdom, which grounds the world and constructs it. ${ }^{56}$

As an evidence of this argument, he notes that "then knowledge and wisdom represent the first means of our prosperity and happiness and its acquisition is a necessary obligation for us and all fellow citizens" "57، Truly, mankind cannot find a capital more precious than sciences and technologies that pave the path for human perfections" ${ }^{98}$ According to Kermani, "knowledge and consciousness that we consider it everyone's capital for happiness is significant and valid for every cause as much as its overall significance suggests" ${ }^{, 59}$

On the other hand, he emphasizes that "it is sciences and technologies that have allowed the European banks to have more money than even our kings have" ${ }^{, 00}$ Mirza Aqa Khan like other intellectuals has spoken of the establishment of companies and railway in Iran and enumerated their benefits. $\mathrm{He}$ believed that this work is beyond the capability and possibilities of his own era; because in that era there was no sufficient knowledge required for the accomplishment of this work and it could not have been done without this knowledge. He addresses the traders and merchants in the following words: "our businessmen cannot form a company together because they do not know what is a company and how one company can build an expensive railway on its own". ${ }^{61}$ These all have their roots in the lack of sufficient knowledge.

\section{KeRMANI's CRITICISMS OF SPENDING WeALTH ON FUtILE CAUSES}

Mirza Aqa Khan has leveled ferocious criticisms and objections against wasting money by Iranians. He raises explicit criticisms against the religious and secular issues and features of people including people's frequent Hajj pilgrimage and spending a considerable amount of money on this cause. W. Benjamin writes: "Such pilgrimages being greatly esteemed in Persia, adding as they do to a repute for piety, far more easily won in this way than by a genuine attempt to live a more holy life."

Clara C. Rice writes in her itinerary: "Here there is a special shrine to which women go in the hope of becoming mothers of sons." "Wealthy women travel with several attendants, and in manner befitting their rank. Pilgrimage is to most people a very costly thing, and women often save up for it for years."

Seeing such enthusiasm among Iranian people for pilgrimage and spending a lot of money in this path spurred the reactions of intellectuals and writers of this era. They compared the industrial and scientific developments in west with traditions in Iran and lamented critically of their native approach to life.

In this spirit, Mirza Aqa Khan Kermani believed that Hajj has destroyed the wealth of Muslims. ${ }^{65}$ Many of the Hajis conducted this pilgrimage in conditions that they themselves described as follows: "we lost all our properties and wealth in order to become Haji. Now we are starving and have nothing

\footnotetext{
56 (Second year, No. 11, 30 Dhu al-Hajji, 1292).

${ }_{58}^{57}$ (Second year, No. 11, 30 Dhu al-Hajji, 1292).

58 (Second year, No. 11, 30 Dhu al-Hajji, 1292).

59 (Second year, No. 10, 29Dhu al-Hajji, 1292).

${ }^{60}$ (Second year, No. 53, 9 Rabi ul Awal, 1293).

${ }^{61}$ Second year, No.48, 2 Rabi ul Awal, 1293)

${ }^{62}$ (Persia and The Persians, London: John Murray,1887, p.208 ).

${ }^{63}$ Persian women and their ways, 1923. P.105).

${ }^{64}$ (Persian women and their ways, 1923. P.105).

65 Three Letters, p. 253
} 
to wear". 66 "Pious efforts of the pilgrims not only did not weaken rather they considered these hardships as a means to purify their souls and bodies ${ }^{167}$ People of this era were ready to face every type of hardship in the path of such pilgrimages and had very firm belief in accomplishing religious obligations and this was the reason why they readily spent such an amount of money in this path. Many people "believed that if someone kills someone or plunders somewhere he could turn his sins to rewards with reading a simple prayer" ${ }^{\prime 68}$

According to Kermani, the statistic that "have been provided by the Europeans suggests that travel to Mecca costs 100 million and this is a huge loss for Muslims; because you have to consider the costs of a one year trip plus six months unemployment as well as two year of chaos for Haji the total sum of which will be more than 1000 Tomans per man" 99

Many Hajis had to bring black slaves to Iran and sell them upon their return to the country in order to cover the costs. ${ }^{70}$ Seeing such enthusiasm among Iranian people for pilgrimage and spending a lot of money in this path spurred the reactions of intellectuals and writers of this era. They compared the industrial and scientific developments in west with traditions in Iran and lamented critically of their native approach to life. The pilgrims who decided to pay a visit to Holy Shrine of Imam Reza (peace be upon him) did undergo numerous hardships because as Grotius has stated, they believed that Imam Reza will stand witness for them in the Day of Judgement. ${ }^{71}$

Among other issues that have been criticized by such intellectuals as Kermani in this era one can refer to indescribable greed of people for garnering useless wealth. In Akhtar he talked of these issues and made comparisons between the behaviors of Europeans and Iranians in order to demonstrate the uselessness of such affairs. As regards the difference of the ways that Europeans and Iranian garner wealth he writes: "Europeans do not burry the money and are not even infatuated with the beauty of money like a mouse. They indeed use money to enhance their welfare and prosperity". ${ }^{72}$

Hiding gold and valuable treasures was not only one the special favorite things of Qajar kings rather this was also done by ordinary people. We have some reports from this era that state: in fact, "in transactions golden coins are not used. These coins are buried in the basements of rich people and are protected very carefully. Some of these coins are spent by the rich people to buy golden and silver precious containers and carpets or jewelries for woman",73

Generally speaking, meaning of wealth in Qajar era can be summarized in one single word, i.e. "gold". Mere having gold and jewelries and precious objects was a sign of the wealthiness of their owner.

The gold was hidden and did not have any profit. Its only function was to create a sense of security. In other words, "gold did not say any word" ${ }^{74}$ According to Heinrich Karl Brugsch who lived in Iran during the era of Nasir al-Din Shah, Iran is not at all a poor country and numerous rich people live in Iran. But due to security considerations they never dared to invest their money on any profitable causes and thus they just tried to keep it hidden somewhere. Moreover, rich people struggled not to allow anyone to be informed of their real wealth and they behaved like the ordinary people. An Iranian in the era of Nasir al-Din Shah was worried always lest the eyes of the neighbors and strangers would see their luxuries and ornaments. For this reason, the rich people and dignitaries preferred to build the forecourt of their mansions simple and without extra ornaments and keep the luxuries for the inside. ${ }^{75}$ In many cases people changed their properties to gold or jewelries and buried them in a

\footnotetext{
${ }^{66}$ Ibid, p 253

${ }^{67}$ (Iranian Papers, Memoirs of Claude Ann's Travel at the Beginning of the Constitutional Revolution, 1989, p. 146).

${ }^{68}$ (Vasily Chuikov's Travel, 1358, p. 39).

${ }^{69}$ (Kermani, Three Letters, p. 252).

${ }^{70}$ (The Qajar Pact, 2005, p.152).

${ }^{71}$ (Grouth's Travel, 1990, p. 34).

72 (Akhtar Newspaper, Year 2, No. 39)

73 (Heinrich Bruges, Journey of The K. Prussian Legation to Persia, p. 123).

${ }^{74}$ Ibid, p 130

75 (From Khorasan to Bakhtiari, 1999, p. 150).
} 
secret corner of their house in order to protect them from the outsiders. Even after the death of the house lord the inheritors could not find the buried gold and jewelries for a while. ${ }^{76}$

Accordingly, "wise people who want not to endanger their properties changed them to jewelries and gilded textiles and other precious objects and hide them in a secret place and sometimes when they are alone they watch them and feel prosperous" "Overall, easterners are greatly interested in jewelries and specifically to colorful types of jewelries like ruby and emerald and this interest is not just a matter of their value; rather they take pleasure of watching them and get impressed of them",78

Dalmani reports that "in the world no other nation is as warried as Iranians of their capital and the reason for this worry lies in the fact that rich people are afraid of the state officers and do not show their properties to the strangers; because the officers would force them to bribe them even in the form of a loan". ${ }^{79}$ In fact, there remains no way but hiding. It was indeed for this very reason that Iranians in the era of Nasir al-Din Shah did not show any interest in establishing companies or economical affairs; because they were afraid of losing their capital. ${ }^{80}$ In this era Nasir al-Din Shah made several efforts to encourage the investors to establish companies inside the country and mobilize their capitals. ${ }^{81}$ However, Iranian capitals in the era of Nasir al-Din Shah Qajar were hidden in secret points of the country. The royal wealth was kept in the treasury and the people's wealth was buried under the soil. In fact, underground in this era was wealthier than the upper ground.

\section{TALIBOV AND THE SPIRIT OF CIVILIZATION WORLD}

Talibov insisted on the importance of wealth for country and called it the spirit of country and nation. ${ }^{82}$ In this respect, he shared ideas with his contemporary intellectual Maraghei. According to Talibov, "wealth is the spirit and manager of the civilization world. In other words, wealth means potency, independency, effort, place and operation that when come together they build the spirit of civilization world or wealth. Although there are words that in our country covey the meaning of wealth: cash, riches, funds, capital, capability, property and so and so forth. However, one needs to know that these together give sense to wealth and they are individually zeros void of meaning and represent nothing as such and they need to combine and make something. As a matter of fact, we do not have any notion of the semantic connotation of wealth let alone its truth" ${ }^{\prime 3}$

Another significant point as regards the debate raised by Talibov is that he has given a new meaning to wealth and denied the traditional meaning of wealth. This new understanding of the wealth has probably had its origin in a semi-developed environment like Caucasus where Talibov lived. His vision of the spiritless and silent economy of Iran as an outsider allowed him to understand that hidden gold and useless mansions and buildings cannot be considered as elements of wealth. ${ }^{84}$ Therefore, according to Talibov, contrary to the mentality that prevails Iran, none of these can be seen as an example of wealth. In his book entitled Ahmad he discusses this issue in interesting terms and expresses his own reasons. Thus, we quote his words in this regard: "cash refers to a piece of metal that is used for transaction; you receive it in return of the debt and exchange it with your needs. Riches mean having garden, servants, horses, caravansaries, farms and the like. Fund means the same. Affluence is the source of revenues. Properties are objects that you can exchange. Now we should see when we have no access to cloth or food and instead of them, we have gold, could we eat or wear gold? No. What about shops and caravansaries? Are they able to feed and cover you? No. Does everyone have gold? No. What about properties like shops and caravansaries? No. Is it possible you have your gold stolen? Yes. Gold and whatever that is built by gold can be drown in sea and burn in fire. The shops and caravansaries will also one day need to be renovated. Then it becomes clear that these cannot be the spirit of civilization world; rather they are just means of transaction. Then, wealth

\footnotetext{
${ }^{76}$ (From Khorasan to Bakhtiari, 1999, p. 116).

77 (From Khorasan to Bakhtiari, 1999, p. 116).

78 (Persia, the land and its inhabitants; Ethnographic descriptions, p. 114).

79 (From Khorasan to Bakhtiari, 1999, p. 116)

${ }^{80}$ Ibid, p 117

${ }^{81}$ Ibid, p 42-43

${ }^{82}$ (Ketabe Ahmad, Vol. 2, p. 120)

${ }^{83}$ (Vol. 2, p. 133).

${ }^{84}$ ( Vol. 2, p. 133).
} 
should be something that can serve as the spirit and manager of the civilization world; and that, as we stated earlier, consists of potency, i.e. knowledge and independence, being immune against the time events and continuing to be" 85

\section{TALibov ON KNOWLEdGe AS WEALth}

Talibov had considered knowledge and independence among wealth and valued it a lot. ${ }^{86}$ It is increasingly significant that Talibov is one of the thinkers who regards knowledge alone wealth. This was indeed a great advance in Qajar intellectual thought of wealth and capital. ${ }^{87}$

He believed in earning knowledge and following the western sciences insofar as he authored his work Ahmad based on Jean-Jacques Rousseau's Emile. ${ }^{88}$

Talibov raises very interesting and ferocious criticism against the economic habits of people of his own age. He states: "we call wealth the spirit of civilized world. There are some narrow minded people who think having several thousands of gold and silver that are just spent for the parties of the rich people from other nations can be a sign of wealth. They are mistaking moon with the sun" ${ }^{89} \mathrm{He}$ concludes that "then admittedly, wealth is a term the meaning of which covers all details of civilization and we proprly call it the spirit and manager of civilization world and in fact our country is not capable of earning it". ${ }^{90}$ Talibov valued knowledge much and believed that the prosperity of human society depends on the development and distribution of sciences. Thus, he provided numerous reasons for the lack of real wealth in Iran of his age. He summarized these reasons as follows: "we do not have any school, we do not have any teacher, our books are just about fairy tales, we have not motive, we have no trainer, thus we have no wealth". ${ }^{91}$ Of course, he takes a number of steps further and claims that if we have law, we will have wealth, knowledge, order and independence. ${ }^{92}$

\section{Malkam and His View of Knowledge, Commerce, Bank and Their Relation with WEALTH}

Qanoon Newspaper is one of the remained examples of the ideas of Malkam and it is different from other newspapers in many respects and Malkam managed to operationalize his ideas in it. ${ }^{93}$ More than anything else, Malkam spoke of the necessity of financial security of people and considered it necessary; because "in every country whose people know that what they earn through work belongs to them they have more incentive to make more efforts and in this way continue to take effective steps for society. On the contrary, whenever people see that they might lose their properties in an unjust manner the nation will see nothing but poverty and wretchedness. Then, as long as a dictatorial system governs the country, economic development will not be but a hallucination"94

Therefore, the first condition for beginning economic activities is the existence of financial security. The issue of social and economic security is so important according to Malkam that "he believes that the first prerequisite of economic and social activity and mobilization of capital" is the existence of this security" 95

and believed that "security of one's life and property is the first condition of prosperity in the world" ${ }^{96} \mathrm{He}$ emphasized on the necessity of foreign investment in the country. ${ }^{97}$ And thus he believed that such sciences as economics and politics are necessary for Iran. ${ }^{98}$

85 (Vol. 2, p. 133-134).

${ }^{86}$ (Vol. 2, p. 133)

${ }^{87}$ (Vol. 2, p. 133).

88 (Iranians and Thought of Modernity, Tehran: Farzan, 1996, p. 79).

${ }^{89}$ (Ketabe Ahmad, Vol. 2, p. 134)

90 (Vol. 2, p. 133)

${ }^{91}$ (., Vol. 2, p. 133)

92 (., Vol. 2, p. 133).

93 (The Iranian Press and Modernization Under the Qajars, 2000, p 215)

94 (Life and Thoughts of Mirza Malkam Khan Nazem al-Dowleh, p. 97).

95 (Investigating the Thoughts of Mirza Malkam Khan Nazem al-Dowleh, 1353, p. 82).

96 (Mirza Malkam Khan Nazem al-Dowleh letters, p. 185)

97 (Pseudo-Modernity in Iran, 2004, p. 82)

98 (Iranian Modernity, Intellectuals and the Intellectual Paradigm of Retardation in Iran, 2001, p. 159). 
According to Malkam, "prosperity of a country depends on the amount of production that is made in it"

In fact, Malkam Khan sees a direct relationship between economic productivity and national prosperity and thus in his view, production and distribution of goods in a society is the measure of poverty and wealth. It is indeed through production of goods that England has earned such amount of wealth (96). Production of goods in a country was so important in his view that he used to say that "the amount of wealth of every country is directly related with the amount of goods that are produced in that country". ${ }^{100}$

In fact, according to Malkam, it is not the type of products that are produced by a country rather it is the amount of the production and distribution of these products that determines the economic status of a country. "Iron, wheat, coal and diamond are among products. Products in trade world do not have any difference. The difference is just related to the price. No one can say that the land where there is gold mines is richer than the land where wheat and tobacco are produced. Every country that can produce more products, no matter if these products are gold or wheat, it is the richer country among other countries. This is not understood by Iranians yet"101“"Asian people do not know that in our age, contrary to the past, a country's wealth is not acquired through war and plunder and every nation that seeks after wealth it should work harder and should produce more products and have more transactions $" 102$ Then, after production we should be able to trade and be active in transactions. This second action is the vehicle through which we can reach wealth. In fact, commerce was so important in the world of those days; insofar as Malkam Khan believed that the axis of prosperity of the world is the affluence of trade. ${ }^{103}$ Following the identification of the importance of production one should state that "in the same way that production of goods is the basis of the production of wealth and results in the welfare and powerfulness of the state, trade can enhance the amount of national currency"104

According to Malkam Khan, "production and wealth in society depend on two factors, i.e. human resources and goods cycle or in other words, commercial transactions"105 "Iranians have various potencies but since they do not have the required capital the whole of natural and human bounties of Iran go useless" 106

As to the importance of companies that have been established in Europe he writes: "one of the wonderful strategies that have been adopted in Europe for trade is a special form cooperation that is called in Europe company. Railways and factories as well as major trades and public buildings and all great factories are built by companies. What is done by companies, i.e. what is built by companies and in collaboration of people is not possible to be handled by the individual citizens alone. Without major companies prosperity for Iran will not be reached"107

It was exactly for the same reason that Malkam Khan offers the aforementioned example. Because if there is no company, nothing will be able to gather the capitals together and make use of them. Of course, in his view, "in the current conditions of Iran, establishment of a company is almost impossible. Establishment of a company requires special laws and bureaucratic orders. None of these laws and orders exists in Iran"108. In a country where law does not exist in its genuine sense as exists in the west and there is no sign of social and economic security no one could ever have any intelligible expectation of the establishment of companies by Iranians themselves. On the other hand, there were also no sufficient information among people concerning the works of companies. And of course, "with the existing laws and traditions in Iran establishment of indigenous companies is among

\footnotetext{
99 (Life and Thoughts of Mirza Malkam Khan Nazem al-Dowleh, p. 96)

100 ( Mirza Malkam Khan Nazem al-Dowleh and Theorization of Iranian Modernity, p. 108).

101 ( Mirza Malkam Khan Nazem al-Dowleh letters, p. 169).

102 (Mirza Malkam Khan Nazem al-Dowleh and Theorization of Iranian Modernity, p. 108).

103 (Mirza Malkam Khan Nazem al-Dowleh letters, p. 172).

104 ( Mirza Malkam Khan Nazem al-Dowleh and Theorization of Iranian Modernity, p. 112).

105 Ibid, p 96

${ }^{106}$ Ibid, p 96

${ }^{107}$ (Mirza Malkam Khan Nazem al-Dowleh letters, p. 189-190).

${ }^{108}$ Ibid, p 190
} 
the baseless imaginations. Foreign companies have to brought into the country in order to make it prosperous" 109 This work, in his view, caused no harm to the country; because "foreign companies work for the nationwide prosperity and this prosperity will be for the nation and state" ${ }^{110}$ As to the importance of bank and railways, Malkam has written in one of his letters: "now it has been revealed that bank, railways and state loans mobilize the world towards prosperity and Iran has no choice but taking this path. The question is that why the officials and authorities dare to deprive the nation from these bounties"111

He believes that it is knowledge that informs us how to use money and money raising in correct way is only possible via knowledge. "Financial problems in social scale are not due to the lack of money rather it is due to the lack of knowledge and tact in us" ${ }^{\prime 12}$ Malkam refutes the ancient maxim that true wealth is gold and struggles to provide effective solutions for economic problems of Iran via scientific arguments and modern science. In his view, the traditions that have been inherited from Shah Tahmasb and Karim Khan Zand cannot address our economic needs in the current age. Economics is not the result of the individual efforts and expansion of simple reason and no as a result of past experiences. It should be taught in the school in scientific way. ${ }^{113}$

Thus conceived, there is a deep relationship between the wealth and knowledge specifically economics and it is via knowledge and science that Europeans have earned so much wealth.

In fact, Malkam Khan uses his comparisons of Iran and Europe to inform Iranians of their lack of consciousness of the methods of earning wealth and struggles to guide them towards the modern advances. Of course, he proposed certain amendments for Islamic laws. ${ }^{114}$ "Malkam Khan's writings suggest that he had truly believed in the domination of knowledge over the superstition, but he did not believe that Islam is superstitious in its nature. As a result, he hoped to protect the religious nature via some revisions of Islamic religion"

In some cases, he "uses his modernist views to support Islam"116

In this regard, he compares Iran with European countries in order to remind Iranians the importance of bank and the new sciences. He argues that "neither British government nor Russian government nor Belgium or Bulgaria have even one penny debt to any other government. Their transactions are handled based on financial techniques none of which is known to our nation. Among these financial techniques it suffices us to know that foreign companies and states in every city have established a factory along with a money treasury that keeps the money earned by the factory and this treasury invests this money in national projects that have public interests" ${ }^{\prime 17}$ In fact, he believed that establishing a bank is the key to production of wealth and investment. ${ }^{118}$

This thought was as such a new solution in that era and was unprecedented. Malkam Khan was the first man who offered the idea of establishment of National Bank ${ }^{119}$ He suggests that bank can gather money and channelize it; because "in Iran money remains useless ... if there was a bank this amount of useless money could be invested on numerous public causes. Both those people who lend their money to the bank as well as those who get loans from bank win the bargain. Due to the lack of bank few people can save their money .... In Europe whoever has money he immediately puts it in the bank and gradually he becomes rich. Contrary to Iran where people no matter how much money they have they will remain wretched" 120

\footnotetext{
${ }^{109}$ Ibid, p 109

${ }^{110}$ Ibid, p 192

111 (Letters of Mirza Malkam Khan Nazem al-Dowleh, by the efforts of Ali Asghar Haghdar, 2008, p. 25).

112 (Mirza Malkam Khan Nazem al-Dowleh letters, p.91).

113 (Mirza Malkam Khan Nazem al-Dowleh and Theorization of Iranian Modernity, p. 107).

114 (A study in the History of Iranian Modernism, HAMID ALGAR, 1973, p78)

115 (The Fourth Wave, 2002, p. 97).

116 ( Confronting Modernity, 2007, First C, p. 134).

117 (Mirza Malkam Khan's literatures, p. 190).

118 ( Mirza Malkam Khan's Life and Thought, p. 99).

${ }^{119}$ Mirza Malkam Khan, 1963, p. 23)

120 (Letters of Mirza Malkam khan Nazem al-Dowleh, p. 224).
} 
the country. This work is done through bank. Otherwise, money as such cannot be of avail. In his view, money is not what our people seem to be. In Europe people see money in another light. In fact, our gold and silver are useful when they are in flow and this is done via bank. "Asian states do not have a correct notion of money. They think that money is tantamount to gold and silver while in Europe money is neither Gold nor silver". ${ }^{21}$ The gold and silver that are hidden under the soil and is inherited by generations and have no use for the prosperity of the country nor for the welfare of people they have no value and they should not be called money.

\section{MOKHBIR AL-SALTANEH: THINKING IS GOLD!}

Numerous descriptions are available in praise of thinking and knowledge specifically from the era of Nasir al-Din Shah. One interesting case in this regard is Mahdiqoli Khan Hedayat Mokhbir alSaltaneh. He has focused more on the modern methods of wealth production. He has also offered a new view of wealth in Qajar era. For example he writes: "some would say that time is gold. We prefer to say instead that thinking is gold. The thought of intelligent people is every day focused on discovering new ways for getting benefitted from natural resources and raise the national wealth" ${ }^{122}$

His criticism of the phrase "time is gold" and changing it into "thinking is gold", in our view, is indeed signaling a great revolution in economic though in Qajar era. In this era we see that with the thoughts of such figures as Taj al-Saltaneh and Mokhbir al-Saltaneh who were princes and had Qajar blood in their veins and such thinkers as Maraghei, Kermani and Talibov a new vision takes form of economy and the concept of wealth.

The issue of importance of knowledge in acquisition of wealth that has been totally reflected in the phrase "thinking is gold" signals the intellectual shift as regards wealth production on the behalf of intellectuals. It was indeed this vision that allowed Mokhbir al-Saltaneh, Talibov and Maraghei to bring about considerable development in this field.

Mokhbir al-Saltaneh was one of the thinkers who like Maraghei, Talibov and Malkam, attached vital significance to bank. He writes in this regard: "bank in other countries is a means for increasing wealth and comfort". ${ }^{123}$ Of course, this issue is raised when bank has been established in Iran but due to mismanagement and wrong policies the establishment of bank had caused numerous harms to the country. ${ }^{124}$

Mokhbir al-Saltaneh had a good command of the market of his own time and this is reflected in his Autobiography through the information that he provides of the trade and allows us to better understand the issue of wealth and economic situation. He believed that before his era, the amount of capital did not matter. It is sales market that is of highest importance. But in that era trade with lesser capital would fail. ${ }^{125}$ In criticism of communistic theory of Karl Marx he states that one of his faults was that he did say that "wealth is the outcome of the labor of worker. In wealth production, we need first thought and knowledge and then the second place is for capital without which thought goes idle. Thought and knowledge and capital are three pillars of production and pave the path for it. They need an intelligent man to manage the task and supervise the worker who is significant in fourth or fifth stage". ${ }^{126}$ Having reiterated this point, he adds that "the wealth that exists today in the Europe is not the result of manual work. It is indeed technology that works in place of thousands of workers and produces more and more. We need to awake from the slumber of negligence and follow their paces. Of course, this has made the workers dissatisfied across Europe"

\section{CONCLUSION}

In Iran of Nasir al-Din Shah's era we are witness to the formation of a current that is known as intellectualism. Intellectuals in this era have become informed of the advances in Europe as well as the wealth that has been acquired through knowledge, technology and industry and concluded that

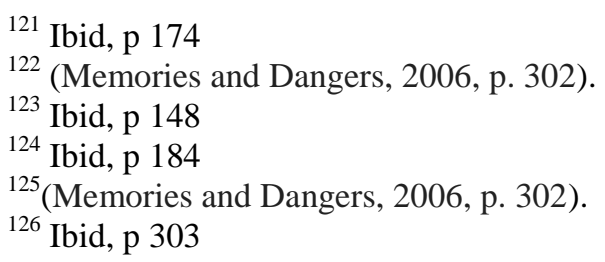


wealth is different from what we deem as wealth in our society. In fact, in their eyes, money, gold, jewelry and land are not wealth as such. Then according to the ideas of such intellectuals as Zein alAbedin Maraghei, Abd al-Rahim Talibov, and Mirza Aqa Khan Kermani, wealth was something through which we could acquire profits and use them. The intellectuals of Nasir al-Din Shah's era were influenced by the ideas of western thinkers and accordingly, criticized the mentality of their people. Mirza Malkam Khan was among the intellectuals of this era who had good information of the conditions of his own age. He was the first one who spoke of the idea of establishment of bank and highlighted the role of bank in mobilization of major capitals. In his works he discusses the way that a bank can be established. Among other issues that are raised by him as regards wealth, one can refer to the issue of knowledge and necessity of its acquisition from westerners, trade, farming and building lands. In his works and Qanoon Newspaper he has discussed wealth in details. The majority of intellectuals in this era ground their criticisms of the current mentality in society of wealth in the ideas of western thinkers. They unanimously argue that money, gold, jewelry and land are not wealth, rather wealth refers to such things as railways, trade, bank, knowledge, joy, pleasure and welfare.

\section{REFERENCES}

[1] Adamiat, F. (1984). Thoughts of Talibouf-e-Tabrizi (Second ed.). Tehran: Damavand Publication.

[2] Anet, C. (n.d.). Iranian Papers, Memoirs of Claude Ann's Travel at the Beginning of the Constitutional Revolution. (I. Proshani, Trans.) Tehran: Moein.

[3] Armaki, T. A. (2001). Iranian's Modernity, Intellectuals and the Intellectual Paradigm of Retardation in Iran. Tehran: Society.

[4] Asil, H. (1997). Mirza Malkam Khan's Life and Thoughts. Tehran: Ney.

[5] Asil, H. (2002). Letters of Mirza Malkam Khane Nazam al-Dowleh. Tehran: Ney.

[6] Asil, H. (2005). Mirza Malkam Khan Nezam al-Dowleh and the Theorizing of Modernity of Iran. Tehran: Kavir.

[7] Bashir, H. (2000). The Iranian Press and Modernization under the Qajar. Center for Mass Communication Research University of Leicester.

[8] Benjamin, S. (1887). Persia and the Persians. London: John Murray, Albemarle Street.

[9] Birjandi, Z. A. (2011). Nasseri's Government and New Discourses. Tehran: Hirmand.

[10] Brugesch, H. (1995). The Journey of the K. Prussian Legation to Persia. Tehran: Centre Publication.

[11] Brugesch, H. (No Data). A Journey to the Court of the Sultan Sahebghran. (H. Kordbache, Trans.) Tehran: Publishing Information.

[12] Burgess, C. a. (1942). Letters from Persia Written. New York: Public Library.

[13] Chirikov, M. (1979). Messi Chirikov Travelogue. (A. A. Omran, Trans.) Tehran: Pocket Books Co.

[14] Curzon, G. N. (1966). Persia and the Persian question. Frank Cass \& Co. LTD.

[15] Daalmani, H. R. (n.d.). From Khorasan to Bakhtiari. (M. A. Farhoshi, Trans.) Tehran, Amir Kabir.

[16] Flora, W. (1986). Essays on Iranian Social History in the Qajar era. Tehran: Tuos Publication.

[17] Gruthe, H. (1990). The Journey of Gruthe. (M. Jalilvand, Trans.) Tehran: Center Publication.

[18] Haghdar, A. (2008). Letters of Mirza Malkam Khan Nazem al-Dowleh. Tehran: Cheshmeh.

[19] Izadi, S. I. (2003). Research on Modern History of Iran . Tehran: Varjevand Publishing.

[20] Jahanbegloo, R. (2002). The Fourth Wave. Tehran: Ney.

[21] Jamshidi, B. (1996). Persians and Thought of Modernity. Teran: Farzan.

[22] Katouzian, M. A. (2013). The Government and Society in Iran (Qajar Extinction and Pahlavi Establishment. (H. Afshar, Trans.) Tehran: Publishing Center.

[23] Katouzian, M. A. (2014). Political Economy of Iran from Constitutional Revolution to the end of Pahlavi Dynasty. (M. R. Azizi, Trans.) Tehran: Publication Center.

[24] Kermani, M. A. (n.d.). Ruznameye Akhtar.

[25] Kermani, M. A. (n.d.). Three Letters. (B. Chubineh, Ed.) Germany, Nima Verlag.

[26] Khan, M. M. (1973). A Study in the History of Iranian Modernism. London: University of California Press.

[27] Maragheii, Z. -o.-A. (2006). Siahat namei e Ebrahim beig. Tehran: Agah.

[28] Masaharo, Y. (1994). Yoshida Masaharo Travelogue. (H. Rajabzadeh, Trans.) Mashhad: Astane Qodse Razavi. 
An Investigation of the Concept and Extensions of Wealth according to the Intellectuals of Qajar Nasir al-Din Shah Era

[29] Milani, A. (2003). Modernity and Modernization in Iran. Tehran: Akhtaran Publishing House.

[30] Mostofi, A. (2009). A Description of my Life (Sixth ed.). Tehran: Zavvar Publishing house.

[31] Nasiri, A. (2007). The Confronting Modernity. Tehran: Science.

[32] Nouri, F. (1974). Investigating the Thoughts of Mirza Malkam Khan Nazimmaldullah. Tehran: POcket Books Co.

[33] Pirzadeh, H. (1963). Haji Pirzadeh Travelougue. Tehran: Tehran university Press.

[34] Polak, J. E. (1982). Persia, The Land and its inhabitants; Ethnographic descriptions. (K. Jahandari, Trans.) Tehran: Kharazmi Publishing Co.

[35] Rezagholi, A. (1994). Sociology of Autocracy. Tehran: Ney.

[36] Rice, C. C. (1923). Persian Women and their Ways. London: Seeley, Service and Co. Limited.

[37] Serena, C. (1984). People and Spectacles of Iran. (G. Samiei, Trans.) Tehran: Noor.

[38] Tabatabaaee, M. (1984). Mirza Malkam Khan's Collections. Tehran: Scientific Publications.

[39] Talibof, A. (1958). Ketab e Ahmad. Shabgir Publishing House.

[40] Vahram, G. (2006). Political System and Social Organizations of Iran during Qajar era. Tehran: Moein.

[41] Vanessa, M. (2005). The Qajar Pact. London: I.B. Touris \& Co. Ltd.

[42] Zarzas, S. (2004). Pseudo-Modernity in Iran. Qom: Center for Sound and Simulation Islamic Studies.

Citation: Elnaz Abeshloo. "An Investigation of the Concept and Extensions of Wealth according to the Intellectuals of Qajar Nasir al-Din Shah Era”. International Journal of History and Cultural Studies (IJHCS). vol 5, no. 1, 2018, pp. 10-24. doi: DOI: http://dx.doi.org/10.20431/2454-7654.0501002.

Copyright: (c) 2019 Authors. This is an open-access article distributed under the terms of the Creative Commons Attribution License, which permits unrestricted use, distribution, and reproduction in any medium, provided the original author and source are credited. 